\title{
THE PRESENCE OF RODENTS INFECTED WITH LEPTOSPIRA BACTERIA IN VARIOUS COUNTRIES AND THE LEPTOSPIROSIS POTENTIAL IN HUMANS: A SYSTEMATIC REVIEW
}

\author{
Rusyda Ihwani Tantia Nova ${ }^{1}$, Dewi Susanna² and Gita Miranda Warsito ${ }^{3}$
}

\author{
${ }^{1}$ Postgraduate student, Master of Public Health, Department of Environmental Health, Faculty of Public Health, Universitas \\ Indonesia, Depok, Indonesia, 16424 \\ ${ }^{2}$ Department of Environmental Health, Faculty of Public Health, Universitas Indonesia, Depok, Indonesia, 16424 \\ ${ }^{3}$ Postgraduate student, Joint Master Degree, Faculty of Public Health, Universitas Indonesia and Curtin University, Depok, \\ Indonesia, 16424
}

Corresponding author: Dewi Susanna

Email: dsusanna@ui.ac.id

\begin{abstract}
Leptospirosis is an infectious disease caused by Leptospira bacteria. It is a global public health concern, especially in tropical and subtropical regions. The aim of this review was to summarize some relevant studies that discuss the presence of rodents and the identification of Leptospira bacteria in rodents. This review also presents findings on the potential reassociation of the presence of rodents with Leptospira bacterial infections to leptospirosis cases in humans. A systematic review methodology used to minimize article selection bias that was likely to occur. During the initial search from three science databases (ProQuest, Scopus, and PubMed), 119 articles were retrieved. During the screening process, three articles were excluded due to duplication, 101 articles were excluded based on title and abstract incompatibility with the inclusion criteria, five articles were excluded due to incompatibility of article content with the inclusion criteria, and two articles were excluded because of the ineligibility with the study. In the final screening process, eight articles were chosen to be analyzed. This review found that the presence of rodents infected with Leptospira had the potential to cause leptospirosis in humans through contaminated water and soil or by direct human-to-human contact. The lead factors in the transmission of leptospirosis infection from rodents to humans are activities that take place in wetlands and rice fields, forestry work, and farming activities.
\end{abstract}

Keywords: Rodents, leptospirosis, Leptospira bacteria, identification, human

\section{INTRODUCTION}

Leptospirosis is an infectious disease caused by Leptospira bacteria ${ }^{1,2}$. Leptospirosis is a global public health concern, especially in tropical and subtropical regions. Leptospira are pathogenic bacteria that are transmitted from animals to humans, either directly or indirectly. In 2014, 97 human leptospirosis cases were identified in the Netherlands, and 13 of those cases involved direct contact with animals ${ }^{3}$. The World Health Organization (WHO) estimates that the number of leptospirosis cases occurring in humans is around 0.1-1 per 100,000 population per year for regions with temperate climates, 10-100 per 100,000 population per year for regions with humid climates, and can reach more than 100 per 100,000 population per year during an outbreak and for groups at high risk of exposure, with a case fatality rate (CFR) of $5 \%-30 \%^{2}$. Leptospirosis is mainly found in humans who come into contact with the urine of infected animals, urine-contaminated surface water and soil in the environment, or drinking water and food that are contaminated with Leptospira ${ }^{1,2}$. Leptospira's portals of entry include cuts and abrasions and mucous membranes, such as conjunctiva, oral, or genital surfaces ${ }^{2,4}$.

Many kinds of animals carry the Leptospira bacteria, including cattle, pigs, goats, buffalos, horses, dogs, rodents, and wild animals ${ }^{2}$. Rodents are recognized as the most common reservoir for causing leptospirosis in human. Rodents that are infected with Leptospira during a hot rainy period are associated with a high incidence of Leptospira infections during a flood ${ }^{5}$. One study showed that, out of 128 patients who displayed leptospirosis-like symptoms, $70 \%$ reported having seen a rodent in their houses, and $29.6 \%$ of them owned dogs 6 . Exposure to rodent urine is associated with acute leptospirosis ${ }^{7}$. Humans that are exposed to rodents have a 1.7-times higher risk for acute leptospirosis than those who are not exposed ${ }^{7}$. 
Various factors enhance the possibility of leptospirosis infection in humans, include hygiene and sanitation, occupational activities, and household environments. In rural communities in Southern Chile, $19.1 \%$ of human drinking water sources were found to be contaminated with Leptospira ${ }^{8,9}$. Personal hygiene factors appear to have the most influence on the risk of transmission in humans. Workers who have wounds (Odds Ratio $(\mathrm{OR})=3.1,95 \% \mathrm{Cl}: 1.5-6.1)$, smoke $(\mathrm{OR}=1.8,95 \%$ $\mathrm{Cl}: 1.1-2.9)$, or eat at the slaughterhouse $(\mathrm{OR}=2.1$, 95\% Cl: 1.2-3.6) have a higher risk for leptospirosis seropositivity than do other workers ${ }^{10}$. Occupational activities and household environments are the major factors in leptospirosis transmission in humans ${ }^{2,8-11}$. The strongest association with leptospirosis in a rural area was the presence of cattle in the houses and people's involvement in wet cultivation. In an urban area, occupational and household activities, such as the use of a public tap, showed a strong association with the risk of Leptospira infection ${ }^{11}$. Moreover, global climate change, severe weather events, and flooding are drivers of leptospirosis in humans ${ }^{12-14}$.

Leptospirosis may present with a wide variety of clinical manifestations, ranging from a mild flu-like illness to a serious and sometimes fatal disease. One common symptom in leptospirosis is icterus (jaundice) $)^{1}$. Shock is a predictor of severe leptospirosis (OR $=14.8,95 \% \mathrm{Cl}: 2.97-73.59)$, and prior steroid use $(\mathrm{OR}=20.2,95 \% \mathrm{Cl}: 1.9-217.5)$ and hemorrhage $(O R=71.2,95 \% \mathrm{Cl}: 4.9-999.9)$ are predictors of death from leptospirosis ${ }^{15}$. Laboratory tests are required to confirm leptospirosis when the disease is suspected on clinical grounds. Leptospirosis is usually diagnosed in the laboratory by detecting antibodies, by culturing the bacteria from blood, urine, or tissues, by demonstrating the presence of Leptospira in tissues using antibodies labelled with fluorescent markers, by polymerase chain reaction $(P C R)$, and immunostaining ${ }^{1}$.

Studies on leptospirosis in humans have looked at determinants ${ }^{17}$, risk factors ${ }^{17}$, environmental influences ${ }^{18}$, and other factors. However, there is still little research that has examined the presence of rodents as vectors of Leptospira and how to identify Leptospira in these rodents.

This systematic review summarizes some relevant studies on the presence of rodents and identification of Leptospira bacteria in rodents. This review also presents findings on the potential reassociation of the presence of rodents with Leptospira bacterial infections to leptospirosis cases in humans. Understanding the presence of rodents and identifying the bacteria Leptospira in rodents will be helpful for the prevention and management of leptospirosis.

\section{METHODS}

\section{Search Strategy}

For this review, articles were retrieved from three science database-ProQuest, Scopus, and PubMed. A systematic review was conducted using a predefined protocol based on PRISMA ${ }^{16}$. The searching process utilized four main keywords that include rodent, leptospirosis identification, human, and public health in various combination. The population in this research is a rodent. The intervention is trapping and laboratory test. The comparison is countries, study characteristics, the types of rodent and type of identification, the outcome is leptospirosis diseases, and the study type is a qualitative method. This research was funded by the Directorate of Research and Community Engagement through Indexed International Publication for Student's Final Project grant no. NKB-0423/UN2.R3.1/HKP.05.00/2019.

In ProQuest, rodent and leptospirosis and human and "'leptospirosis identification" or identification or "identification of leptospirosis") and "public health" as a keyword. Full text, type of source is an academic journal, date of publication last 10 years are included in the filter. The search strategy in Scopus: TITLE-ABS-KEY ( rodent AND leptospirosis AND human AND ( "leptospirosis identification" OR identification OR "identification of leptospirosis" ) AND "public health") AND ( LIMIT-TO ( DOCTYPE, "ar" ) )

In Pubmed : (("rodentia"[MeSH Terms] OR "rodentia"[All Fields] OR "rodent"[All Fields]) AND ("leptospirosis"[MeSH Terms] OR "leptospirosis"[All Fields]) AND ("humans"[MeSH Terms] OR "humans"[All Fields] OR "human"[All Fields])) AND (("leptospirosis"[MeSH Terms] OR "leptospirosis"[All Fields]) AND ("identification (psychology)"[MeSH Terms] OR ("identification"[All Fields] AND "(psychology)"[All Fields]) OR "identification (psychology)"[All Fields] OR "identification"[All Fields])) OR ("identification (psychology)"[MeSH Terms] OR ("identification"[All Fields] AND "(psychology)"[All Fields]) OR "identification (psychology)"[All Fields] OR "identification"[All Fields]) OR (("identification (psychology)"[MeSH Terms] OR ("identification"[All Fields] AND "(psychology)"[All Fields]) OR "identification (psychology)"[All Fields] OR "identification"[All Fields]) AND ("leptospirosis"[MeSH Terms] OR "leptospirosis"[All Fields]))) AND "public health"[All Fields] AND ("loattrfull text"[sb] AND "2009/07/16"[PDat] : "2019/07/13"[PDat])s

\section{Inclusion and Exclusion criteria}

All original articles in English, academic or research articles, cross-sectional and case control research, and the articles looking at the presence of rodent, 
identification Leptospira bacteria in rodent and leptospirosis in human are included. The study about presence of rodent but not identified Leptospira bacteria, identified Leptospira bacteria in human, animals that carry leptospirosis other than a rodent, review articles, case report, outbreak report, and qualitative method, experimental and prospective research are excluded. Experimental and prospective research excluded because there are various kinds of interventions that can cause differences in results with other studies.

\section{Study Selection}

The study selection was carried out by three reviewers, who determine the articles' eligibility to be reviewed from the title, abstract, and full text. The reviewer is chosen based on the area of expertise.

\section{Data Extraction}

Data extracted from the chosen eligible studies are, the authors, study period, publishing year, country where the research was conducted, research design and research methods, area of research, result related with the presence of rodent (types of rodents, no rodent of a trapped, sample that used to identified Leptospira bacteria, Leptospira identification in rodent (positive or negative)

\section{Data synthesis}

Data synthesis will be planned using narrative synthesis. The research area is categorized into three categories, rural areas, suburban areas, and urban areas. Rural areas located outside of cities and towns. Rural areas have low population density, a lot of undeveloped lands, farmland or forest ${ }^{17}$. Suburban areas are lower density areas that separate residential and commercial areas from one another. It is either part of a city or urban or exist as a separate residential community within commuting distance of a city ${ }^{18}$. Urban areas are locations with high population density, city, and town ${ }^{19}$. The types of rodents and the number of rodents trapped will be reviewed based on research area categories, methods will be a review based on the result of a laboratory test (positive or negative), and the sample that used to identified Leptospira bacteria will be review base on the result of laboratory test (positive or negative). To minimize risk bias of individual studies the three reviewers worked independently. If they were in disagreement it will be avoided by the discussion process and reading the whole article. Data was analysed by univariate analysis.

\section{RESULT}

There is no risk bias in this systematic review. There were 119 articles retrieved during the initial searching (ProQuest $=103$, Scopus $=7$, and Pubmed $=9$ ). During the screening process, 3 articles were excluded because of duplication, 101 articles were excluded based on title and abstract incompatibility with the inclusion criteria, 5 articles were excluded due to incompatibility of article content with the inclusion criteria, 2 articles were excluded because of the ineligibility with the study. In the final screening process 9 articles were chosen to be analyzed (Figure 1).

Of the 9 eligible articles, 2 were conducted in Southeast Asia, 2 were covered island country, 2 were conducted in South and North America, one was carried in Western Europe, and one was conducted in South Asia. The most common articles were published in $2017(\mathrm{n}=4)$, four articles were published in 2010, 2014, 2015, and 2018. All eligible articles that will be reviewed don't clearly state the study design. However, from the method used and the time of the study, it can be seen that all of the articles used a cross-sectional study. The samples in this study were humans and rodents. Human sera retrospectively analyzed from leptospirosis cases confirmed by molecular diagnosis from January 2014 to April 2015 at the medical diagnosis laboratory of the Institut Louis Malarde (ILM) and laboratory test (RT-qPCR). Rodent's samples were taken using traps, and laboratory test for Leptospira identification. Reverse Transcription Polymerase Chain Reaction (RT-PCR) is the most laboratory test that used to confirm the Leptospira bacteria in human and rodents (Table 1 ).

Area of study consist of rural, suburban, and urban areas. Most often in urban and rural areas. In Southeast Asia, seventeen species of rodents were founded. The most species of rodents were trapped is Rattus exulans $(n=220)$. Rattus novergicus $(n=84)$ is the fewest species of rodents was founded in Western Europe. The most Sample that used to identify Leptospira bacteria in rodents is kidney with PCR methods. Of the 2.104 rodents trapped, 1.247 in rural areas, 848 in urban areas, and 9 in the suburban area. The rodents were infected with Leptospira bacteria is 555 rodents and 1.549 rodents were not infected (Table 2). From 8 extracted studies was found the lead factors to transmission leptospirosis infection from rodents to human is activities taking place in wetlands and rice fields, forestry work, and farming activities.

\section{DISCUSSION}

Rodents are common reservoir Leptospira bacteria that cause leptospirosis cases in human ${ }^{2}$. Based on the results of systematic reviews that have been 
conducted, from 8 scientific research articles carried out in the various country, it was recorded that 30 species of rodent have been identified for the possibility of Leptospira bacteria infection. The diversity of species and the number of rodents trapped in each country varies greatly. Based on the tabulation of the results of the research, it can be seen that this diversity is very significant in each country. Based on continental regions, in the Southeast Asia region, the most found species were Rattus exulans $(\mathrm{n}=220)$, in the island country and Western Europe the most common species were Rattus norvegicus $(n=175)(n=84)$, in North America the most common species is Mus muculus $(n=302)$, and in South America, the most common species is Oligoryzomys microtis $(\mathrm{n}=69)$.

Rodent species are distributed in different regions. However, the similar species were found in different regions, such as Rattus norvegicus. This species was found in Western Europe and Southeast Asia. In this systematic review Oligoryzomys microtis is only found in Peru, South America.

Diversity is also seen in each research areas (rural, suburban, and urban). The division of research areas was based on population density and development progress in the area ${ }^{17-19}$. In the rural area, rodent species that were mostly caught were Mus Musculus, Rattus exulans, and Rattus rattus. The number of rodents trapped in the rural area is 1.247 rodents. In the suburban area, the rodent species trapped was Rattus norvegicus (n-9). And rodent species trapped in urban area are Rattus norvegicus, and Oligoryzomys microtis. The number of rodents trapped in the urban area is 848 rodents. Based on the systematic review carried out, the type of rodent species and the number of rodents trapped in a research area in accordance with the ecology and rodent habitat. Mus musculus is a house mouse that is closely related to humans. These animals live in homes, outdoor buildings, shops, and other building structures ${ }^{28}$. Rattus exulans, is a species that is very related to humans. These habitats are in villages, homes, fields, rice fields, coconut plantations, sugar cane plantations, grasslands, and shrubs ${ }^{29}$. Rattus rattus is an Idomalayan species. Rattus rattus widespread in the forest and woodlands and being able to live in and around the building, on the ground, aboveground, and belowground. Rattus norvegicus is a species that is widespread on roads, rivers, lakes, and beaches. Rattus norvegicus habitat is in agriculture, horticulture, grasslands, forests, inland areas, and places that are rarely planted ${ }^{30}$. Oligoryzomys microtis is found in tropical forests and the edges of forests. This species is spread in, Bolivia, the Plurinational States of, Brazil, Paraguay, and Peru. It has a very restricted and unique habitat ${ }^{31}$.
Based on the research results tabulation, it is known that the number of rodents trapped can be influenced by the length of research, and the area of research. The highest number of rodents trapped in Southeast Asia is 1.04, with a very wide research area and consisting of several countries, as well as varied research times, starting from 2009 until 2010, and in 2017.

Of the 1.247 rodents trapped were identified by using laboratory tests. Laboratory test carried out with various methods, such as culture, MAT, and PCR. Each of these methods has advantages and disadvantages. For cultures methods, this method is very sensitive but takes a long time. MAT is to determine agglutination antibodies in the patient's serum. This methods is very complicated and requires many types of serovar, very complicated when monitoring, implementing and evaluating results. The PCR method is divided into two, conventional PCR and real-time PCR (RT-PCR).

Conventional PCR is a method used to ascertain Leptospira bacteria by finding specific Leptospira DNA segments. This method is very helpful for diagnosing leptospirosis in the early stages of the disease. The weakness of this method is that it is unable to identify the type of infecting serovar. RTPCR has high sensitivity and specificity, low risk of cross-contamination, and able to detect large quantities of samples and shirt time so that the result can be known more quickly. The weakness of this method is that it requires expensive equipment and reagents ${ }^{32}$. In this systematic review, PCR and RT-PCR are the most methods used.

The sample that used to identify Leptospira bacteria is urine, blood, and kidney. The kidney is the most widely used sample in this systematic review. It is because Leptospira bacteria live and breed in tubules konvoluta (kidney) ${ }^{33}$. Leptospira bacteria can not live and breed in urine and blood. It dies quickly. To avoid bias in identifying Leptospira bacteria it is strongly recommended not to use only one method and one sample. Based on the results of laboratory tests, 555 rodents were tested positive infected Leptospira bacteria. The presence of rodents infected with Leptospira bacteria has the potential to cause leptospirosis disease, especially in humans. This is because rodents trapped are rodent species that live and breed closely related to humans. Rodents infected with Leptospira bacteria will release fluid from their bodies like urine then contaminate water and soil around their habitat ${ }^{2}$. The condition of the environment, poor sanitation, will also increase the risk for leptospirosis. This is in line with the results of previous studies which said that environments such as floods and heavy rain are the driving factors for the occurrence of leptospirosis in $\mathrm{Asia}^{34}$. 


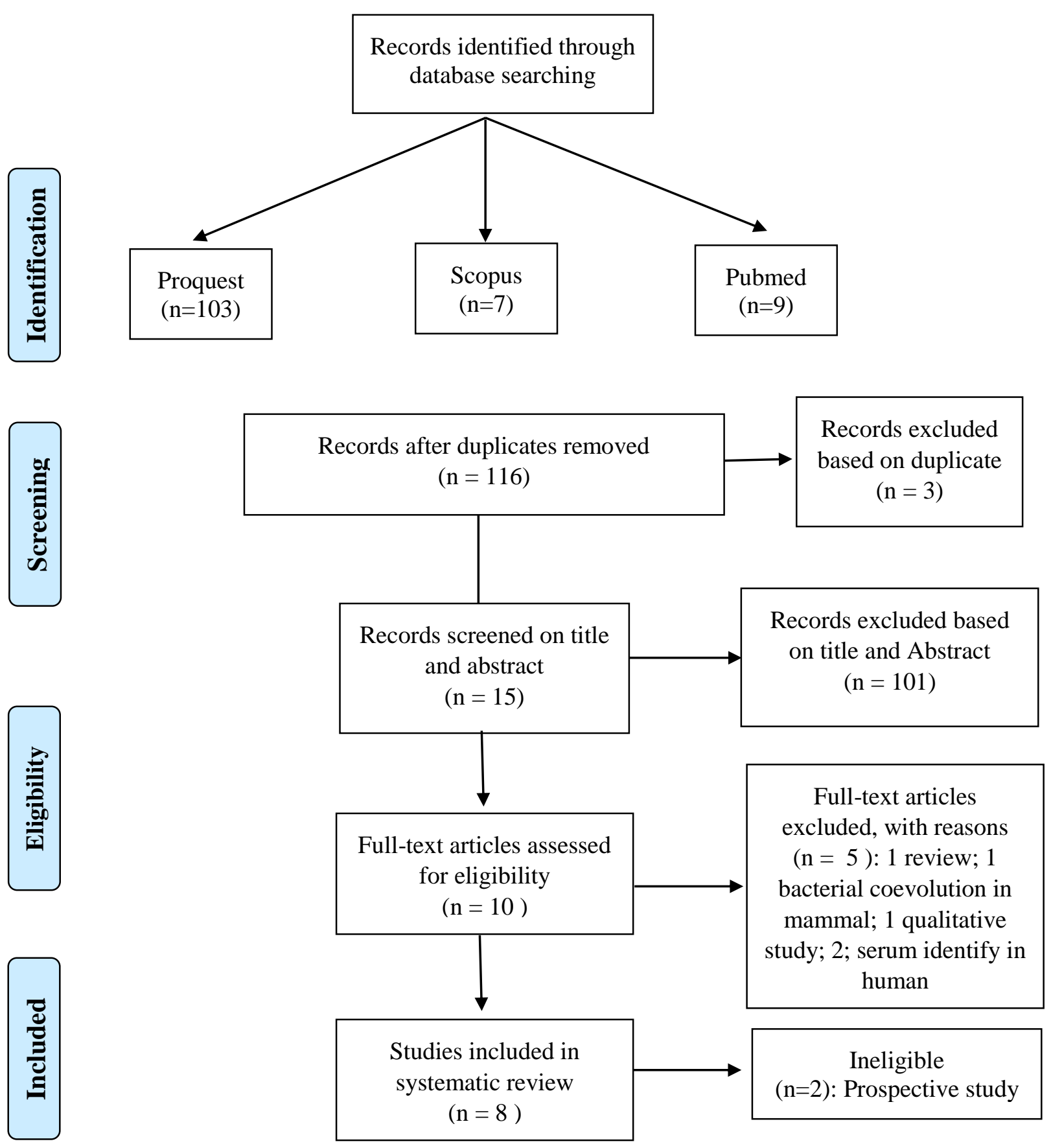

Figure 1: Flowchart of Systematic Review (PRISMA) ${ }^{16}$ 
Table 1. Articles Characteristics

\begin{tabular}{|c|c|c|c|c|c|c|}
\hline No & Authors & $\begin{array}{l}\text { Study } \\
\text { Period }\end{array}$ & $\begin{array}{c}\text { Published } \\
\text { *year }\end{array}$ & Country & Design & Methods \\
\hline 1. & $\begin{array}{l}\text { Latifah, I, Abdul Halim, A, Rahmat, } \\
\text { M S, Nadia, M F; Ubil, Z E; Asmah, } \\
\text { H; Shafariatul Akmar, I; Picardeau, } \\
\text { M; Siti Haslina, O; Nasir, M A }{ }^{20}\end{array}$ & 2016 & 2017 & Malaysia & $\begin{array}{c}\text { Cross- } \\
\text { Sectional }\end{array}$ & $\begin{array}{l}\text { Trapping and } \\
\text { laboratory test } \\
\text { (Culture in } \\
\text { EMJH, and PCR) }\end{array}$ \\
\hline 2. & $\begin{array}{l}\text { Panti-May, J.; De Andrade, R R C; } \\
\text { Gurubel-González, Y; Palomo- } \\
\text { Arjona, E; Sodá-Tamayo, L; Meza- } \\
\text { Sulú, J; Ramírez-Sierra, M; } \\
\text { Dumonteil, E; Vidal-Martínez, V M; } \\
\text { Machaín-Williams, C; De Oliveira, } \\
\text { D; Reis, M G; Torres-Castro, M A; } \\
\text { Robles, M R; Hernández- } \\
\text { Betancourt, S F; Costa, F'1 }\end{array}$ & 2013 & 2017 & Mexico & $\begin{array}{l}\text { Cross- } \\
\text { Sectional }\end{array}$ & $\begin{array}{l}\text { Trapping and } \\
\text { laboratory test } \\
\text { (PCR) }\end{array}$ \\
\hline 3. & $\begin{array}{l}\text { Ayral, Florence; Zilber, Anne- } \\
\text { Laure; Bicout, Dominique J; Kodjo, } \\
\text { Angeli; Artois, Marc; Djelouadji, } \\
\text { Zoheira22 }\end{array}$ & $\begin{array}{l}2011- \\
2012\end{array}$ & 2015 & France & $\begin{array}{l}\text { Cross- } \\
\text { Sectional }\end{array}$ & $\begin{array}{l}\text { Trapping and } \\
\text { laboratory test } \\
\text { (qPCR and MST) }\end{array}$ \\
\hline 4. & $\begin{array}{l}\text { Cosson, Jean-Francois; Picardeau, } \\
\text { Mathieu; Mielcarek, Mathilde; } \\
\text { Tatard, Caroline; Chaval, Yannick; } \\
\text { Suputtamongkol, Yupin; Buchy, } \\
\text { Philippe; Jittapalapong, Sathaporn; } \\
\text { Herbreteau, Vincent; Morand, } \\
\text { Serge }^{23}\end{array}$ & $\begin{array}{l}2009- \\
2010\end{array}$ & 2014 & $\begin{array}{l}\text { Thailand, } \\
\text { Laos, and } \\
\text { Cambodia }\end{array}$ & $\begin{array}{l}\text { Cross- } \\
\text { Sectional }\end{array}$ & $\begin{array}{l}\text { Trapping and } \\
\text { laboratory test } \\
\text { (RT-PCR) }\end{array}$ \\
\hline 5. & $\begin{array}{l}\text { Rahelinirina, Soanandrasana; Léon, } \\
\text { Albertine; Harstskeerl, Rudy A; } \\
\text { Sertour, Natacha; Ahmed, Ahmed; } \\
\text { Raharimanana, Claudine; Ferquel, } \\
\text { Elisabeth; Garnier, Martine; } \\
\text { Chartier, Loïc; Duplantier, Jean- } \\
\text { Marc; Rahalison, Lila; Cornet, } \\
\text { Muriel }^{24}\end{array}$ & $\begin{array}{l}2008- \\
2009\end{array}$ & 2010 & Madagascar & $\begin{array}{l}\text { Cross- } \\
\text { Sectional }\end{array}$ & $\begin{array}{l}\text { Trapping and } \\
\text { laboratory test } \\
\text { (MAT, PCR hap } \\
1 \text {, culture, any } \\
\text { test) }\end{array}$ \\
\hline 6. & $\begin{array}{l}\text { Denipitiya, D. T. H; } \\
\text { Chandrasekharan, N V; } \\
\text { Abeyewickreme, W; Hartskeerl, R } \\
\text { A; Hapugoda, M D }{ }^{25}\end{array}$ & $\begin{array}{l}2012- \\
2013\end{array}$ & 2017 & Sri Lanka & $\begin{array}{l}\text { Cross- } \\
\text { Sectional }\end{array}$ & $\begin{array}{l}\text { Trapping and } \\
\text { laboratory test } \\
\text { (PCR and MAT) }\end{array}$ \\
\hline 7. & $\begin{array}{l}\text { Cortez, Valerie; Canal, × Enrique; } \\
\text { Dupont-Turkowsky, J Catherine; } \\
\text { Quevedo, Tatiana; Albujar, } \\
\text { Christian;Ti-Cheng, Chang; Salmon- } \\
\text { Mulanovich, Gabriela; Guezala- } \\
\text { Villavicencio, Maria C; Simons, } \\
\text { Mark P; Margolis, × Elisa; Schultz- } \\
\text { Cherry, Stacey; Pacheco, Víctor; } \\
\text { Bausch, Daniel G26 }\end{array}$ & $\begin{array}{l}2014- \\
2015\end{array}$ & 2018 & Peru & $\begin{array}{l}\text { Cross- } \\
\text { Sectional }\end{array}$ & $\begin{array}{l}\text { Trapping and } \\
\text { laboratory test } \\
\text { (culture in EMJH } \\
\text { and RT-PCR) }\end{array}$ \\
\hline 8. & $\begin{array}{l}\text { Guernier, Vanina; Vaea, Richard; } \\
\text { Nhan, Tuxuan; Rouault, Eline; } \\
\text { Tessier, Anita; Musso, Didier }{ }^{27}\end{array}$ & $\begin{array}{l}2014- \\
2015\end{array}$ & 2017 & $\begin{array}{l}\text { French } \\
\text { Polynesia }\end{array}$ & $\begin{array}{l}\text { Cross- } \\
\text { Sectional }\end{array}$ & $\begin{array}{l}\text { Human sera: } \\
\text { laboratory test } \\
\text { (RT-qPCR) }\end{array}$ \\
\hline & & & & & & $\begin{array}{l}\text { Animals: } \\
\text { Trapping and } \\
\text { laboratory test } \\
\text { (RT-qPCR) }\end{array}$ \\
\hline
\end{tabular}




\section{Table 2. Research Outcome of The Reviewed Articles}

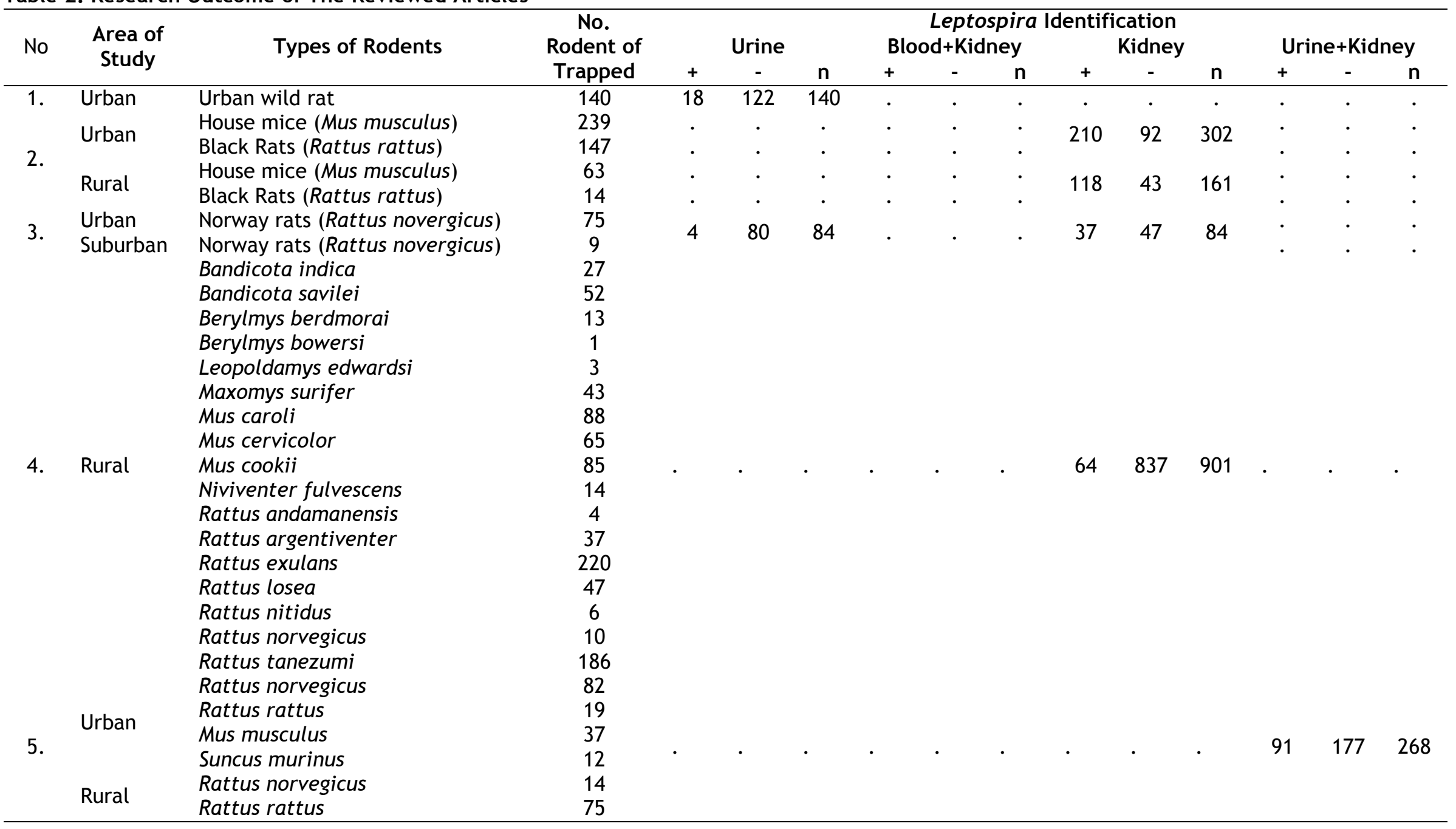


Table 2. (Continued)

\begin{tabular}{|c|c|c|c|c|c|c|c|c|c|c|c|c|c|c|c|}
\hline \multirow[t]{3}{*}{ No } & \multirow{3}{*}{$\begin{array}{c}\text { Area of } \\
\text { Study }\end{array}$} & \multirow[t]{3}{*}{ Types of Rodents } & \multirow{3}{*}{$\begin{array}{c}\text { No. } \\
\text { Rodent of } \\
\text { Trapped }\end{array}$} & \multicolumn{12}{|c|}{ Leptospira Identification } \\
\hline & & & & \multicolumn{3}{|c|}{ Urine } & \multicolumn{3}{|c|}{ Blood+Kidney } & \multicolumn{3}{|c|}{ Kidney } & \multicolumn{3}{|c|}{ Urine+Kidney } \\
\hline & & & & + & - & $\mathbf{n}$ & + & - & $n$ & + & - & $\mathbf{n}$ & + & - & $n$ \\
\hline & & Mus musculus & 18 & & & & & & & & & & & & \\
\hline & & Suncus murinus & 11 & & & & & & & & & & & & \\
\hline 6. & Rural & Rattus rattus & 38 & . & . & . & 4 & 34 & 38 & . & . & . & . & . & . \\
\hline \multirow[t]{10}{*}{7.} & Urban & Euryoryzomys nitidus & 2 & . & . & . & . & . & . & . & . & . & 23 & 74 & 97 \\
\hline & & Holochilus sciureus & 1 & & & & & & & & & & & & \\
\hline & & Hylaeamys perenensis & 5 & & & & & & & & & & & & \\
\hline & & Neacomys amoenus & 1 & & & & & & & & & & & & \\
\hline & & Necromys lenguarum & 10 & & & & & & & & & & & & \\
\hline & & Oligoryzomys microtis & 69 & & & & & & & & & & & & \\
\hline & & Oxymycterus inca & 3 & & & & & & & & & & & & \\
\hline & & Proechimys brevicauda & 1 & & & & & & & & & & & & \\
\hline & & Proechimys pattoni & 1 & & & & & & & & & & & & \\
\hline & & Proechimy simonsi & 4 & & & & & & & & & & & & \\
\hline \multirow[t]{3}{*}{8.} & Rural & Rattus norvegicus & 79 & . & . & . & . & . & . & 23 & 90 & 113 & . & . & . \\
\hline & & Rattus rattus & 28 & & & & & & & & & & & & \\
\hline & & Rattus exulans & 6 & & & & & & & & & & & & \\
\hline
\end{tabular}


The lead factors to transmission leptospirosis infection from rodents to human is activities taking place in wetlands and rice fields, forestry work, and farmers. Leptospirosis is a disease caused by work ${ }^{39}$. Risk work is work that has contact with air, mud and soil that supports transmission of leptospirosis. This is because the Leptospira bacteria can survive in the air, and also moist soil ${ }^{1,2}$. Types of works that are at risk are farmers, sugar cane farmers, breeders, cleaning workers, abattoir workers, fish and ungags processing, butchers, laboratory workers, miners, garbage transporters in endemic areas, market workers, veterinarians, and other jobs that are related to the environment contaminated with Leptospira bacteria or Leptospira bacterial habitat ${ }^{39,40}$.

The limitations of this research are not doing a meta-analysis and the strengths of this research are to use data from reliable sources. For further research, it is recommended to research the types of Leptospira bacteria that infected rodents and humans in one region. Vector control is needed to reduce the potential transmission of rodent that infected Leptospira bacteria to human.

\section{CONCLUSION}

Rodent species are distributed in different regions. In the rural area, rodent species that were mostly caught were Mus Musculus, Rattus exulans, and Rattus rattus. In the suburban area, the rodent species trapped was Rattus norvegicus and rodent species trapped in urban area are Rattus norvegicus, and Oligoryzomys microtis. Laboratory test carried out with various methods, such as culture, MAT, and PCR. PCR has high sensitivity and specificity. The presence of rodents that infected with Leptospira bacteria has the potential to cause leptospirosis in human with contaminating water and soil or direct contact with a human. The lead factors to transmission leptospirosis infection from rodents to human is activities taking place in wetlands and rice fields, forestry work, and farming activities.

\section{ACKNOWLEDGEMENTS}

We would like to thank the Directorate of Research and Community Engagement through Indexed International Publication for Student's Final Project grant for financial support.

\section{REFERENCES}

1. World Health Organization. Human Leptospirosis: Guidance for Diagnosis, Surveillance and Control [Internet]. Geneva: World Health Organization; 2003. iii. Available from: https://apps.who.int/iris/bitstream/h andle/10665/42667/WHO_CDS_CSR_EP H_2002.23.pdf; jsessionid=409A63D77E5 B29922E817B7731BADE27? sequence $=1$

2. Centers for Disease Control and Prevention. Leptospirosis Fact Sheet for Clinicians [Internet]. Cdc. 2018. Available from: https://www.cdc.gov/leptospirosis/pd $\mathrm{f} / \mathrm{fs}$-leptospirosis-clinicians-eng508.pdf

3. Pijnacker R, Goris MGA, Te Wierik MJM, Broens EM, van der Giessen JWB, de Rosa $M$, et al. Marked increase in leptospirosis infections in humans and dogs in the Netherlands, 2014. Euro Surveill [Internet]. 2016 Apr 28 [cited 2019 May 6];21(17):30211. Available from:

http: / / www.eurosurveillance.org/View Article. aspx?Articleld=22463

4. Haake, David A and Levett PN. Leptospirosis in Human. Vol. 387, PubMed Central. 2015. 65-97 p.

5. Perez J, Brescia F, Becam J, Mauron C, Goarant C. Rodent Abundance Dynamics and Leptospirosis Carriage in an Area of Hyper-Endemicity in New Caledonia. PLoS Negl Trop Dis [Internet]. 2011 Oct;5(10):e1361. Available from: https://search.proquest.com/docview /1288103698? accountid $=17242$

6. Romero-Vivas $C M E$, Cuello-Pérez $M$, Agudelo-Flórez $\mathrm{P}$, Thiry $\mathrm{D}$, Levett $\mathrm{PN}$, Falconar AKI. Cross-sectional study of Leptospira seroprevalence in humans, rats, mice, and dogs in a main tropical sea-port city. Am J Trop Med Hyg [Internet]. 2013 Jan 9 [cited 2019 May 6];88(1):178-83. Available from: http://www.ajtmh.org/content/journa ls/10.4269/ajtmh.2012.12-0232

7. Maze MJ, Cash-Goldwasser S, Rubach MP, Biggs HM, Galloway RL, Sharples KJ, et al. Risk factors for human acute leptospirosis in northern Tanzania. PLoS Negl Trop Dis [Internet]. 2018 Jun;12(6). Available from: https://search.proquest.com/docview / 2070854729 ? accountid $=17242$

8. Muñoz-Zanzi C, Mason M, Encina C, Astroza A, Romero A. Leptospira Contamination in Household and 
Environmental Water in Rural Communities in Southern Chile. Int $\mathrm{J}$ Environ Res Public Health [Internet]. 2014 Jun 26 [cited 2019 May 6];11(7):6666-80. Available from: http: / /www.mdpi.com/1660-

4601/11/7/6666

9. Allwood $P$, Muñoz-Zanzi C, Chang $M$, Brown PD. Knowledge, perceptions, and environmental risk factors among Jamaican households with a history of leptospirosis. J Infect Public Health [Internet]. 2014;7(4):314-22. Available from:

http: / /www.sciencedirect.com/scienc e/article/pii/S1876034114000458

10. Cook EAJ, de Glanville WA, Thomas LF, Kariuki S, Bronsvoort BM de C, Fèvre EM. Risk factors for leptospirosis seropositivity in slaughterhouse workers in western Kenya. Occup Environ Med [Internet]. $2017 \quad$ May;74(5):357. Available from: https://search.proquest.com/docview / 1894826720 ?accountid $=17242$

11. Muñoz-Zanzi C, Mason MR, Encina C, Astroza A, Romero A. Leptospira contamination in household and environmental water in rural communities in southern Chile. Int $\mathrm{J}$ Environ Res Public Health [Internet]. 2014;11(7):6666-80. Available from: https://www.scopus.com/inward/reco rd.uri?eid=2-s2.0-

$84903398872 \&$ doi $=10.3390 \% 2 F i j e r p h 11$

0706666\&partnerID=40\&md5=6a571448 9bf926d2e8f00c4fdd101d32

12. Prabhakaran SG, Shanmughapriya S, Dhanapaul S, James A, Natarajaseenivasan K. Risk factors associated with rural and urban epidemics of leptospirosis in Tiruchirappalli District of Tamilnadu, India. J Public Health (Bangkok) [Internet]. 2014 Aug;22(4):323-33. Available from: https://search.proquest.com/docview /1546078875? accountid=17242

13. Lau CL, Watson $\mathrm{CH}$, Lowry JH, David MC, Craig SB, Wynwood SJ, et al. Human Leptospirosis Infection in Fiji: An Ecoepidemiological Approach to Identifying Risk Factors and Environmental Drivers for Transmission. PLoS Negl Trop Dis [Internet]. 2016 Jan;10(1). Available from:

https://search.proquest.com/docview / 1764354607 ? accountid $=17242$

14. Lau C, Smythe L, Weinstein P. Leptospirosis: An emerging disease in travellers. Travel Med Infect Dis [Internet]. 2010 Jan;8(1):33-9. Available from: https://search.proquest.com/docview $/ 1027115849$ ? accountid $=17242$

15. Londe LDR, Da Conceição RS, Bernardes $T$, Dias MCDA. Flood-related leptospirosis outbreaks in Brazil: perspectives for a joint monitoring by health services and disaster monitoring centers. Nat Hazards [Internet]. 2016 Nov;84(2):1419-35. Available from: https://search.proquest.com/docview / 1828863084 ? accountid $=17242$

16. Wang $\mathrm{H}-\mathrm{K}$, Lee $\mathrm{M}-\mathrm{H}$, Chen $\mathrm{Y}-\mathrm{C}$, Hsueh $\mathrm{P}$ $\mathrm{R}$, Chang $\mathrm{S}-\mathrm{C}$. Factors associated with severity and mortality in patients with confirmed leptospirosis at a regional hospital in northern Taiwan. J Microbiol Immunol Infect [Internet]. 2018; Available from http://www.sciencedirect.com/scienc e/article/pii/S1684118218301610

17. Allwood $P$, Muñoz-Zanzi $C$, Chang $M$, Brown PD. Knowledge, perceptions, and environmental risk factors among Jamaican households with a history of leptospirosis. J Infect Public Health [Internet]. 2014;7(4):314-22. Available from:

https://www.scopus.com/inward/reco rd.uri?eid=2-s2.0-

$84904049026 \&$ doi $=10.1016 \% 2 F j . j i p h .20$

14.03.004\&partnerID $=40 \& \mathrm{md} 5=3 \mathrm{e} 1 \mathrm{~d} 242$ a91a8c07b90028d834c5354fc

18. Mohd Ridzuan J, Aziah BD, Zahiruddin WM. Work Environment-Related Risk Factors for Leptospirosis among Plantation Workers in Tropical Countries: Evidence from Malaysia. Int J Occup Environ Med. 2016 Jul;7(3):15663.

19. Costa F, Ribeiro GS, Felzemburgh RDM, Santos N, Reis RB, Santos AC, et al. Influence of Household Rat Infestation on Leptospira Transmission in the Urban Slum Environment. Small PLC, editor. PLoS Negl Trop Dis [Internet]. 2014 Dec 4 [cited 2019 May 6];8(12):e3338. 
Available from: http://dx.plos.org/10.1371/journal.pn td.0003338

20. Moher D, Liberati A, Tetzlaff J, Altman DG, Altman D, Antes G, et al. Preferred reporting items for systematic reviews and meta-analyses: The PRISMA statement (Chinese edition). J Chinese Integr Med. 2009;7(9):889-96.

21. Tennessee Department of Health. Rural Areas [Internet]. [cited 2019 Jul 23]. Available from: https://www.tn.gov/health/cedep/en vironmental/healthy-places/healthyplaces/land-use/lu/rural-areas.html

22. Tennessee Department of Health. Suburban Areas [Internet]. [cited 2019 Jul 23]. Available from: https://www.tn.gov/health/cedep/en vironmental/healthy-places/healthyplaces/land-use/lu/suburbanareas.html

23. Tennessee Department of Health. Urban Areas [Internet]. [cited 2019 Jul 23]. Available from: https://www.tn.gov/health/cedep/en vironmental/healthy-places/healthyplaces/land-use/lu/urban-areas.html

24. Latifah I, Abdul Halim A, Rahmat MS, Nadia MF, Ubil ZE, Asmah $\mathrm{H}$, et al. Isolation by culture and PCR identification of LipL32 gene of pathogenic Leptospira spp. in wild rats of Kuala Lumpur. Malays J Pathol. 2017 Aug;39(2):161-6.

25. Panti-May JA, De Andrade RRC, Gurubel-González Y, Palomo-Arjona E, Sodá-Tamayo L, Meza-Sulú J, et al. A survey of zoonotic pathogens carried by house mouse and black rat populations in Yucatan, Mexico. Epidemiol Infect [Internet]. 2017;145(11):2287-95. Available from: https://www.scopus.com/inward/reco rd.uri?eid=2-s2.0-

$85021870557 \&$ doi $=10.1017 \% 2 F S 0950268$ $817001352 \&$ partnerID=40\&md5=e301 a9 1ee5581f35d99d492fb5cb2630

26. Ayral F, Zilber A-L, Bicout DJ, Kodjo A, Artois M, Djelouadji Z. Distribution of Leptospira interrogans by Multispacer Sequence Typing in Urban Norway Rats (Rattus norvegicus): A Survey in France in 2011-2013. PLoS One [Internet]. 2015

Oct;10(10). Available from: https://search.proquest.com/docview / 1720193585 ? accountid $=17242$

27. Cosson J-F, Picardeau $M$, Mielcarek $M$, Tatard C, Chaval Y, Suputtamongkol Y, et al. Epidemiology of Leptospira Transmitted by Rodents in Southeast Asia. PLoS Negl Trop Dis [Internet]. 2014 Jun;8(6):e2902. Available from: https://search.proquest.com/docview /1547568941 ?accountid=17242

28. Rahelinirina $S$, Léon A, Harstskeerl RA, Sertour N, Ahmed A, Raharimanana C, et al. First Isolation and Direct Evidence for the Existence of Large SmallMammal Reservoirs of Leptospira sp. in Madagascar. PLoS One [Internet]. 2010 Nov;5(11). Available from: https://search.proquest.com/docview /1292205933? accountid $=17242$

29. Denipitiya DTH, Chandrasekharan N V, Abeyewickreme W, Hartskeerl RA, Hapugoda MD. Identification of cattle, buffaloes and rodents as reservoir animals of Leptospira in the District of Gampaha, Sri Lanka. BMC Res Notes [Internet]. 2017;10. Available from: https://search.proquest.com/docview $/ 1883238433$ ? accountid $=17242$

30. Cortez V, Canal $\times$ Enrique, DupontTurkowsky JC, Quevedo T, Albujar C, Ti-Cheng $C$, et al. Identification of Leptospira and Bartonella among rodents collected across a habitat disturbance gradient along the InterOceanic Highway in the southern Amazon Basin of Peru. PLoS One [Internet]. 2018 Oct;13(10). Available from:

https://search.proquest.com/docview /2117502176? accountid $=17242$

31. Guernier V, Vaea R, Nhan T, Rouault E, Tessier A, Musso D. Leptospira diversity in animals and humans in Tahiti, French Polynesia. PLoS Negl Trop Dis [Internet]. 2017 Jun;11(6). Available from:

https://search.proquest.com/docview / 1919505321 ?accountid=17242

32. Global Invasive Species Database. Species Profile: Mus Musculus. 2015.

33. Csurhes S. Invasive animal risk assessment: Pacific rat Rattus exulans 
[Internet]. 2012. Available from: http://creativecommons.org/licenses/ by/3.0/au/\%5Cnhttp://creativecommo ns.org/licenses/by/3.0/au/deed.en

34. Hausser J, de Roguin L. Rattus norvegicus. Säugetiere der Schweiz / Mammifères de la Suisse / Mammiferi della Svizzera. 2013;283-7.

35. Patton, J.L., Weksler, M., Bonvicino, C.R. \& Percequillo A. Oligoryzomys microtis , Small-eared Pygmy Rice Rat Errata version. IUCN Red List Threat Species. 2017;8235:1-8.

36. Setiawan I. Pemeriksaan Laboratorium Untuk Mendiagnosis Penyakit Leptospirosis. Media Penelit dan Pengemb Kesehat. 2008;18(1):44-52.

37. Rampengan NH. Leptospirosis. J Biomedik. 2016;8(3):143-50.

38. Mwachui MA, Crump L, Hartskeerl R, Zinsstag J, Hattendorf J. Environmental and Behavioural Determinants of Leptospirosis Transmission: A Systematic Review. PLoS Negl Trop Dis [Internet]. 2015;9(9). Available from: https://www.scopus.com/inward/reco rd.uri?eid=2-s2.0-

84943196151\&doi=10.1371\%2Fjournal.p ntd. $0003843 \&$ partner ID $=40 \& m d 5=4 b 4 e$ e214c2a52b4f48b4f87829e9c39b

39. Meny $P$, Menéndez $C$, Ashfield N, Quintero $\mathrm{J}$, Rios C, Iglesias $\mathrm{T}$, et al. Seroprevalence of leptospirosis in human groups at risk due to environmental, labor or social conditions. Rev Argent Microbiol [Internet]. 2019; Available from http://www.sciencedirect.com/scienc e/article/pii/S0325754119300069

40. Kementerian Kesehatan RI. Petunjuk Teknik Pengendalian Leptospirosis. 2017;126. 